\title{
The Streptomyces coelicolor genome encodes a type I ribosome-inactivating protein
}

Correspondence

Jozef Anné

Jozef.anne@rega.kuleuven.be

Received 15 February 2010

Revised 22 June 2010

Accepted 28 June 2010

\author{
Ana G. Reyes, ${ }^{1,2} \uparrow$ Nick Geukens, ${ }^{1} \dagger \ddagger$ Philip Gutschoven, ${ }^{1}$ \\ Stijn De Graeve, ${ }^{3,4}$ René De Mot, ${ }^{5}$ Armando Mejía ${ }^{2}$ and Jozef Anné ${ }^{1}$
}

\footnotetext{
${ }^{1}$ Laboratory of Bacteriology, Rega Institute for Medical Research, Katholieke Universiteit Leuven, Minderbroedersstraat 10, B-3000 Leuven, Belgium

${ }^{2}$ Departamento de Biotecnología, División de Ciencias Biológicas y de la Salud, Universidad Autónoma Metropolitana, Mexico City, Mexico

${ }^{3}$ VIB Department of Molecular Microbiology, Kasteelpark Arenberg 31, B-3001 Heverlee-Leuven, Belgium

${ }^{4}$ Laboratory of Molecular Cell Biology, Institute of Botany and Microbiology, Katholieke Universiteit Leuven, B-3001 Heverlee-Leuven, Belgium

${ }^{5}$ Centre of Microbial and Plant Genetics, Department of Microbial and Molecular Systems, Faculty of Bioscience Engineering, Katholieke Universiteit Leuven, B-3001 Heverlee-Leuven, Belgium
}

Ribosome-inactivating proteins (RIPs) are cytotoxic $N$-glycosidases identified in numerous plants, but also constitute a subunit of the bacterial Shiga toxin. Classification of plant RIPs is based on the absence (type I) or presence (type II) of an additional lectin module. In Shiga toxin, sugar binding is mediated by a distinct RIP-associated homopentamer. In the genome of two actinomycetes, we identified RIP-like proteins that resemble plant type I RIPs rather than the RIP subunit (StxA) of Shiga toxin. Some representatives of $\beta$ - and $\gamma$-proteobacteria also contain genes encoding RIP-like proteins, but these are homologous to StxA. Here, we describe the isolation and initial characterization of the RIP-like gene product SCO7092 (RIPsc) from the Gram-positive soil bacterium Streptomyces coelicolor. The ripsc gene was expressed in Escherichia coli as a recombinant protein of about $30 \mathrm{kDa}$, and displayed the characteristic $N$-glycosidase activity causing specific rRNA depurination. In Streptomyces lividans and E. coli, RIPsc overproduction resulted in a dramatic decrease in the growth rate. In addition, intracellular production was deleterious for Saccharomyces cerevisiae. However, when applied externally to microbial cells, purified RIPsc did not display antibacterial or antifungal activity, suggesting that it cannot enter these cells. In a cell-free system, however, purified S. coelicolor RIPsc protein displayed strong inhibitory activity towards protein translation.

\section{INTRODUCTION}

Ribosome-inactivating proteins (RIPs) are cytotoxic $\mathrm{N}$ glycosidases that inhibit protein synthesis by virtue of their enzymic activity, selectively cleaving a specific adenine residue from a highly conserved, surface-exposed stemloop (sarcin-ricin loop) structure in 28S rRNA (Park et al.,

†These authors contributed equally to this work.

‡Present address: PharmAbs, The K.U.Leuven Antibody Center, Herestraat 49 box 824, B-3000 Leuven, Belgium.

Abbreviations: qRT-PCR, quantitative RT-PCR; RIP, ribosome-inactivating protein.

Two supplementary figures, showing a multiple sequence alignment of representative RIPs from plants, A subunits of Shiga toxins and RIP-like proteins from bacteria, and a dendrogram constructed from the alignment, are available with the online version of this paper.
2006). RIPs show depurination activity against eukaryotic and prokaryotic rRNA in the presence and absence of ribosomal proteins (Endo et al., 1991). Depurination of the sarcin-ricin loop prevents binding of elongation factor 2 to the ribosome, thereby resulting in protein synthesis inhibition (Stirpe et al., 1992; Stirpe, 2004).

Currently, RIPs isolated from plants are divided into two major groups based on the presence or absence of a lectinlike chain, which makes a significant functional difference. Type I RIPs consist of a single polypeptide chain of about $30 \mathrm{kDa}$, whereas type II RIPs consist of an enzymically active A chain similar to type I RIPs, linked by a disulphide bond to a slightly larger (approximately $35 \mathrm{kDa}$ ) B chain, which has the properties of a lectin with specificity for galactosecontaining carbohydrates (Barbieri et al., 1993; Stirpe, 2004). The best-known type II RIP is ricin (Lord et al., 1994). 
Only the presence of type II RIPs has been confirmed in bacteria (Suh et al., 1998; Sandvig, 2001). These potent type II RIPs that contain a glycosphingolipid-binding moiety are produced by Shigella dysenteriae (Shiga toxin) and several other pathogenic bacteria, including certain strains of Escherichia coli (Shiga-like toxins or verotoxins) (Sandvig, 2006). In this toxin the enzymically active monomeric subunit (StxA) is non-covalently associated with a homopentameric sugar-binding module (Johannes \& Römer, 2010).

Although the enzymic and biological activities of RIPs have been extensively investigated, and for several the crystal structure has been elucidated (Stirpe \& Battelli, 2006; Ng et al., 2010), their precise physiological role is still subject to debate. Plant RIPs are generally suggested to be defencerelated proteins, as they are able to inhibit the multiplication and growth of several pathogenic viruses, fungi and bacteria either alone or in conjunction with other defencerelated proteins. On the other hand, their wide distribution in plants suggests that they have an important role, giving an evolutionary advantage that justifies their conservation (Girbés et al., 2004).

In this manuscript, we describe the analysis of a gene (designated ripsc) from Streptomyces coelicolor, genetically the best-characterized Streptomyces species (Bentley et al., 2002), with an orthologue in Streptomyces lividans that encodes a protein with significant homology to previously described type I RIPs. We studied the biological properties and antimicrobial activities of this putative RIP homologue encoded by SCO7092.

\section{METHODS}

Strains, media and growth conditions. E. coli strain TG1 was used as host for cloning purposes (Sambrook et al., 1989). Cultures were grown at $37{ }^{\circ} \mathrm{C}$ (with shaking at 300 r.p.m.) in Luria-Bertani medium, supplemented with the appropriate antibiotics. S. coelicolor M145 and S. lividans TK24 and their derivatives were precultured in $5 \mathrm{ml}$ phage medium (Korn et al., 1978) supplemented with the appropriate antibiotics, when needed, and grown at $27{ }^{\circ} \mathrm{C}$ with continuous shaking at 250 r.p.m. for 48 h. After homogenizing the mycelium, the strains were inoculated in liquid Nutrient broth-MOPS medium (NM) (Van Mellaert et al., 1994). For solid media, mannitol soya flour (MS) (Kieser et al., 2000) or MRYE medium was used (Anné et al., 1990) supplemented with thiostrepton $\left(10 \mu \mathrm{g} \mathrm{ml}^{-1}\right)$, where applicable. Protoplast formation and subsequent transformation of S. lividans were carried out as described previously (Kieser et al., 2000). For the yeast toxicity test, Saccharomyces cerevisiae strains W303-1A and BY4743 were grown on selective plates [synthetic dextrose (SD)-His] and in liquid [synthetic complete (SC)-His $2 \%$ raffinose] medium at $30{ }^{\circ} \mathrm{C}$. Saccharomyces cerevisiae cells were transformed using the Gietz method (Gietz et al., 1995). For evaluation of RIPsc antifungal activity, fungi were grown on YPD agar plates ( $1 \%$ yeast extract, $2 \%$ peptone, $2 \%$ glucose, $2 \%$ agar) at $27{ }^{\circ} \mathrm{C}$ for $48 \mathrm{~h}$.

DNA manipulation and vector construction. For all DNA manipulations standard techniques were used (Sambrook et al., 1989; Kieser et al., 2000). Restriction endonucleases and DNA-modifying enzymes were obtained from Invitrogen and Roche Diagnostics.
For overexpression of ripsc in S. lividans, the gene encoding the predicted mature RIPsc protein was amplified by PCR with the primers $5^{\prime}$-TACTGCAGATACGCCCAACAGGC- $3^{\prime}$ and 5' ${ }^{\prime}$ TACTTAAGTCACCTTTGCCCGTTGATGGC-3' using chromosomal DNA of S. coelicolor M145 as a template. After verification of the DNA sequence, the ripsc gene was cloned as a PstI-T4 DNA polymerasetreated/EcoRI fragment downstream of the vsi promoter and signal sequence into pBSDK0.6Sma (Lammertyn, 2000), treated with DraIIKlenow polymerase/EcoRI, resulting in pBSvsirip. Finally, the complete expression cassette containing the vsi promoter, vsi signal sequence and the ripsc sequence encoding the mature protein was transferred as an $X b a \mathrm{I} / E c o R I$ fragment from pBSvsirip to the corresponding sites of the Streptomyces plasmid pIJ486 (Ward et al., 1986). The resulting vector pIJ486vsirip was used for overexpression of ripsc in S. lividans.

pET-RIPsc used for the overproduction and subsequent purification of N-terminally 6His-tagged RIPsc from E. coli was constructed by inserting an $\mathrm{NdeI} / \mathrm{BamHI}$ fragment encoding the mature RIPsc protein into the corresponding sites of pET3a. This latter fragment encoding mature RIPsc was amplified by PCR using S. coelicolor M145 chromosomal DNA as template with the primers MatRIPscF (5' -TACATATGCACCATCATCACCATCACGATACGCCCAACAGGC- $3^{\prime}$ ) and RIPscR (5'-TAGGATCCTCACCTTTGCCCGTTGATGGC- $3^{\prime}$ ). The MatRIPscF primer also contained a 6 His-encoding sequence to allow subsequent affinity purification.

To test the toxicity of RIPsc in Saccharomyces cerevisiae, a galactoseinducible expression system available in Saccharomyces cerevisiae W3031A and BY4743 strains (Thomas \& Rothstein, 1989; Brachmann et al., 1998 ) was used. For this purpose, the $S$. coelicolor putative rip gene was amplified by PCR with the primers $5^{\prime}$-TAGGATCCGATACGCCCAACAGGC-3' and 5'-TACCTAGGTCACCTTTGCCCGTTGATGGC-3') using chromosomal DNA of S. coelicolor M145 as a template. The amplified sequence was cloned in pGEM-T Easy (Promega). After DNA sequence verification and determination of the orientation of the cloned ripsc fragment, the ripsc gene was obtained as a BamHI (restriction site present in the $5^{\prime}$ primer)/ApaI (restriction site present in the pGEM-T Easy vector) fragment and cloned in the corresponding sites of the pESC-His vector (Stratagene), downstream of the Saccharomyces cerevisiae GAL1 promoter for galactose-inducible expression in yeast, resulting in plasmid pESCripsc.

RNA isolation. Total RNA from samples was isolated using the SV Total RNA isolation System from Promega according to the manufacturer's protocol. Samples were stored at $-80{ }^{\circ} \mathrm{C}$. Yields and RNA integrity were determined on an Eppendorf biophotometer.

RIPsc overproduction in $\boldsymbol{E}$. coli and purification. For the overproduction of 6His-tagged mature RIPsc, E. coli BL21(DE3)pLysS cells were transformed with the expression plasmid pET-RIPsc, grown at $37{ }^{\circ} \mathrm{C}$ and induced with $1 \mathrm{mM}$ IPTG as described by Studier et al. (1990). Subsequently, the cultures were grown at $37{ }^{\circ} \mathrm{C}$ for an additional 4 h. E. coli cells producing 6 His-tagged mature RIPsc were harvested by centrifugation $\left(10 \mathrm{~min}, 5000 \mathrm{~g}, 4{ }^{\circ} \mathrm{C}\right)$. The obtained pellet was resuspended in $10 \mathrm{ml}$ inclusion bodies sonication buffer $[25 \mathrm{mM}$ HEPES, $100 \mathrm{mM} \mathrm{KCl}, 12.5 \mathrm{mM} \mathrm{MgCl}_{2}, 20 \%$ (v/v) glycerol, $0.1 \%$ (v/v) Nonidet P-40, 1 mM DTT, pH 7.7], with the addition of one EDTA-free protease inhibitor tablet (Roche) and $500 \mu \mathrm{l}$ lysozyme $\left(10 \mathrm{mg} \mathrm{ml}^{-1}\right)$, and then incubated for $30 \mathrm{~min}$ on ice. Next, the suspension was incubated for $1 \mathrm{~h}$ at $-80{ }^{\circ} \mathrm{C}$, after which the suspension was thawed in water at room temperature and sonicated eight times for $15 \mathrm{~s}$. The inclusion bodies were pelleted by centrifugation at 10000 r.p.m. at $4{ }^{\circ} \mathrm{C}$ for $10 \mathrm{~min}$. The pellet was washed 10 times with RIPA buffer $[0.1 \%(\mathrm{w} /$ v) SDS, $1 \%(\mathrm{v} / \mathrm{v})$ Triton X-100, $1 \%(\mathrm{w} / \mathrm{v})$ sodium deoxycholate in Trisbuffered saline (TBS; $25 \mathrm{mM}$ Tris/ $\mathrm{HCl}, \mathrm{pH} 7.5,150 \mathrm{mM} \mathrm{NaCl}$ )] and stored at $-20{ }^{\circ} \mathrm{C}$ until use. 
The isolated inclusion bodies were resuspended in $8 \mathrm{M}$ urea, $\mathrm{pH}$ 8.0. After incubation for $1 \mathrm{~h}$ at room temperature, the sample was cleared by centrifugation $(10 \mathrm{~min}, 10000 \mathrm{~g}$ ), and 6His-tagged RIPsc was purified from the sample by affinity chromatography under denaturing conditions $\left(8 \mathrm{M}\right.$ urea) on a $\mathrm{Ni}^{2+}$-nitriloacetate (NTA) column (IBA) as recommended by the manufacturer. The obtained fractions were screened for the presence of RIPsc using SDS-PAGE and fractions containing the desired protein were pooled. Finally, urea in the protein samples was removed by gel filtration on a PD-10 column (GE Healthcare), which had been previously equilibrated with $10 \mathrm{mM}$ Tris/HCl, $\mathrm{pH}$ 7.5. Using this procedure, typically $250 \mu \mathrm{g}$ pure RIPsc could be obtained. Anti-RIPsc antibodies were raised against purified RIPsc samples in rabbits, as described by Geukens et al. (2001).

Separation of soluble and insoluble protein fractions. For separating soluble and insoluble fractions from the bacterial cell lysates, cells from a $1 \mathrm{ml}$ RIPsc-producing E. coli culture were harvested after 2, 3 and $4 \mathrm{~h}$ induction with IPTG by centrifugation $(3 \mathrm{~min}, 10000 \mathrm{~g}$ ). The cell pellets were resuspended in $57 \mu \mathrm{l}$ ATRIT [10\% (w/v) sucrose, $50 \mathrm{mM}$ Tris/ $\mathrm{HCl}, \mathrm{pH} 8]$ with the addition of $19 \mu$ lysozyme solution $\left(20 \mathrm{mg} \mathrm{ml}^{-1}\right)$ and incubated for $15 \mathrm{~min}$ at room temperature. After incubation, $76 \mu$ l CTRIT [0.2\% (v/v) Triton $\mathrm{X}-100,50 \mathrm{mM}$ EDTA, $50 \mathrm{mM}$ Tris/ $\mathrm{HCl}, \mathrm{pH}$ 8] was added. The samples were vortexed and next incubated for $5 \mathrm{~min}$ at room temperature. The cells were lysed by freeze-thawing, after which the samples were centrifuged for $5 \mathrm{~min}$ at $10000 \mathrm{~g}$. The supernatant, corresponding to the soluble protein fraction, was mixed with $25 \mu \mathrm{l}$ protein loading dye and analysed by SDS-PAGE. The remaining pellet, i.e. the insoluble protein fraction, was washed with $150 \mu \mathrm{l}$ BTRIT (25 mM EDTA, $25 \mathrm{mM}$ Tris/ $\mathrm{HCl}, \mathrm{pH}$ 8), resuspended in $167 \mu \mathrm{l}$ TRIT (3 vols ATRIT, 1 vol. BTRIT and 4 vols CTRIT) and mixed with $33 \mu \mathrm{l}$ protein loading dye for subsequent analysis by SDS-PAGE.

SDS-PAGE and Western blotting. The protein fractions from the bacterial extracts were resolved on $12.5 \%$ SDS-PAGE and stained with Coomassie brilliant blue. To confirm the identity of the resulting bands, the bacterial protein samples were transferred onto a PVDF membrane and probed with anti-RIPsc antibodies. Immunodetection was performed using anti-rabbit IgG labelled with alkaline phosphatase using a colorimetric method with nitroblue tetrazolium chloride (NBT)/5-bromo-4-chloro-3' ${ }^{\prime}$-indolyl phosphate $p$-toluidine salt (BCIP) as substrates.

In vitro protein translation inhibition assay. Purified RIPsc was tested for in vitro protein synthesis inhibition activity using the rabbit reticulocyte lysate system (Promega). The translation was performed according to the manufacturer's protocol using luciferase mRNA. The translation products were detected using the Transcend nonradioactive translation system (Promega) by chemiluminescence. Rabbit reticulocyte lysate $(35 \mu \mathrm{l})$ was incubated for $30 \mathrm{~min}$ at $30{ }^{\circ} \mathrm{C}$ in the presence of purified RIPsc protein (500, 250 and $125 \mathrm{ng}$ ). Similar amounts of RNase-free buffer $(10 \mathrm{mM}$ Tris/ $\mathrm{HCl}, \mathrm{pH} 7.5$, $100 \mathrm{mM} \mathrm{NaCl}$ ) or RNase-free water were used as controls. To these mixtures, $1 \mu \mathrm{l}$ amino acid complete mixture, RNasin RNase inhibitor (40 U, Promega), $100 \mathrm{ng}$ luciferase mRNA and $1.5 \mu \mathrm{l}$ Transcend tRNA were added, and next RNase-free water was added to a final volume of $50 \mu \mathrm{l}$. After the initiation of translation, the samples were further incubated at $30^{\circ} \mathrm{C}$ for $1 \mathrm{~h}$, after which the samples were placed on ice to stop the reaction. In order to detect the translation products, $15 \mu \mathrm{l}$ protein loading dye was added to $5 \mu$ l reaction mixture and heated to $90{ }^{\circ} \mathrm{C}$ for $2 \mathrm{~min}$. The denatured samples were separated by $12.5 \%$ SDS-PAGE, transferred to a PVDF membrane and subsequently treated according to the manufacturer's protocol for chemiluminescence detection (Promega). The bands were visualized using X-ray films.
Determination of $\boldsymbol{N}$-glycosidase activity. Adenine released from ribosomes by RIPsc-overproducing $E$. coli was determined using quantitative RT-PCR (qRT-PCR), as described by Melchior \& Tolleson (2010). In brief, two pairs of primers were designed. One pair, which anneals upstream from the RIPsc-affected site of the $23 \mathrm{~S}$ ribosome subunit, was used as a control. The other pair was designed to specifically detect the alternate sequence, with the $\mathrm{A} \rightarrow \mathrm{T}$ transversion, in the $23 \mathrm{~S}$ ribosome subunit. The $3^{\prime}$ end base of the reverse primer (in bold type) matches the base in the altered sequence but does not match the base of the native sequence. The third base counting from the $3^{\prime}$ end (underlined) is a mismatch with both sequences. In this way, the last codon $3^{\prime}$-terminal from the reverse primer totally mismatches the native sequence. Consequently, qRTPCR amplification of the native $23 \mathrm{~S}$ ribosome sequence is much lower than that of the altered sequence. The following primers were used: control forward primer, 5' -ATGTCGGCTCATCACATCCTGGGG-3'; control reverse primer, 5' -CCCAGCTCGCGTACCACTTTAAA-3'; test forward primer, 5' ${ }^{\prime}$-ACTGAGGGGGGCTGCTCCTAGTA-3'; test reverse primer, 5' -TGCGTCCACTCCGGTCCACA-3' .

Real-time PCR was performed in a Rotor-Gene RG-3000 thermal cycler (Corbett Research) using One-Step SYBR GreenER chemistry from Invitrogen. Reactions with a $20 \mu \mathrm{l}$ total volume were prepared, containing $5 \mathrm{ng}$ total E. coli RNA $\mu \mathrm{l}^{-1}$ and $0.2 \mu \mathrm{M}$ of each appropriate pair of primers. Each RNA sample was run in triplicate with both pairs of primers. Corbett Research software was used to obtain threshold cycle $\left(C_{\mathrm{T}}\right)$ numbers. Total amplicon concentration was determined from ripsc cDNA obtained by RT-PCR.

Yeast toxicity assay. RIPsc toxicity was tested by intracellular production in yeast cells. Therefore, a galactose-inducible expression system in Saccharomyces cerevisiae strains W303-1A and BY4743 was used (Thomas \& Rothstein, 1989; Brachmann et al., 1998). These strains, transformed with pESCripsc and the empty pESC-His plasmid, were subsequently inoculated on selective plates (SD-His) and incubated for 3 days. In order to test RIPsc toxicity to yeast, a spot test was performed with these transformants. Three independent colonies were picked up to inoculate liquid medium (SC-His 2\% raffinose), and after 2 days incubation at $30{ }^{\circ} \mathrm{C}$, cell densities were measured. The cell suspensions were diluted to the same density with sugar-free SC-His medium. Samples $(5 \mu \mathrm{l})$ of different dilutions $\left(\mathrm{OD}_{600} 1,0.1\right.$ and 0.001$)$ of Saccharomyces cerevisiae pESC and Saccharomyces cerevisiae cells harbouring pESC-ripsc were spotted on selective plates with glucose to block RIPsc expression or with galactose to induce RIPsc production.

Assay for antifungal activity. The antifungal activity of purified RIPsc was determined by a radial growth inhibition assay adapted from the method of Schlumbaum et al. (1986). Various fungal plugs were placed in the centre of YPD agar plates and sterile paper discs were placed next to the fungal plugs. The fungal plugs were inoculated with $5 \mu \mathrm{l}$ of cultures of Fusarium oxysporum, Trichoderma reesei, Saccharomyces cerevisiae and Aspergillus niger, and grown at $27^{\circ} \mathrm{C}$ for $48 \mathrm{~h}$ in YPD medium. Purified RIPsc protein $(50 \mu \mathrm{g})$, which was sterilized using a $0.22 \mu \mathrm{m}$ pore-size filter (Millipore), was pipetted onto the discs. The plates were then incubated in the dark at room temperature. Antifungal activity was scored as a crescent-shaped zone of inhibition at the mycelial front.

Assay for antibacterial activity. Antibacterial activity of RIPsc was tested using a growth inhibition plate assay. Staphylococcus aureus, Staphylococcus epidermidis, Pseudomonas aeruginosa, E. coli, Micrococcus luteus and Bacillus subtilis strains were inoculated in liquid Luria-Bertani medium and incubated at $37{ }^{\circ} \mathrm{C}$ for $12 \mathrm{~h}$. These cultures were used to inoculate inhibition plates with an inoculation loop. The inhibition plates were made by mixing $10 \mathrm{ml} \mathrm{LB}$ agar with $100 \mu \mathrm{g}$ purified RIP solution $\left(10 \mu \mathrm{g} \mathrm{ml}{ }^{-1}\right.$ final concentration) 
sterilized by filtration $(0.22 \mu \mathrm{m}$ pore-size, Millipore). The plates were incubated at $37{ }^{\circ} \mathrm{C}$ for $12 \mathrm{~h}$ and antibacterial activity was measured.

\section{RESULTS}

\section{Computer-assisted analysis of the $S$. coelicolor RIP homologue SC07092}

BLASTP analyses (http://www.expasy.ch/tools/blast/) indicated that the deduced amino acid sequence of $S$. coelicolor SCO7092 (RIPsc) has substantial similarity to known RIPs from plants. This is consistent with the presence of the Pfam motif for RIP proteins (PF00161, E=1.2 e-07; http// pfam.sanger.ac.uk/). The PSORTb software (http://www. psort.org/psortb/) was used to predict the subcellular localization of RIPsc. The RIPsc protein is predicted to be secreted by S. coelicolor. The SignalP3.0 software identified an $\mathrm{N}$-terminal signal peptide of 35 amino acids with high probability. This predicted signal peptide has the characteristic $\mathrm{N}$-, $\mathrm{H}$ - and $\mathrm{C}$-domains and contains a typical type I signal peptidase cleavage site in the C-domain. The mature RIPsc protein is predicted to have a molecular mass of $29 \mathrm{kDa}$, a $\mathrm{pI}$ of 8.1 and potential $N$-glycosidase activity (http://www.expasy.ch/tools/protparam.html).

Sequence alignment of the $S$. coelicolor RIP-like protein SCO7092 and its S. lividans orthologue shows that the RIP active site residues are conserved in these actinomycete proteins (Fig. 1 and Supplementary Fig. S1). This is also the case for a number of other bacterial hypothetical proteins revealed by genome sequence analysis, each containing a putative amino-terminal signal peptide for secretion (Supplementary Fig. S1). Comparative sequence analysis indicated that the genomes of Burkholderia sp. CCGE1002 (a $\beta$-proteobacterial soil isolate) and Rickettsiella grylli (a $\gamma$ proteobacterial pathogen of arthropods; Leclerque, 2008) encode RIPs clustering with Shiga toxin A subunits, although a homologue of the toxin B subunit appears to be absent (Fig. 1 and Supplementary Fig. S2). Remarkably, SCO7092 shows only a low level of sequence homology with the RIP domain in the hypothetical proteins from two

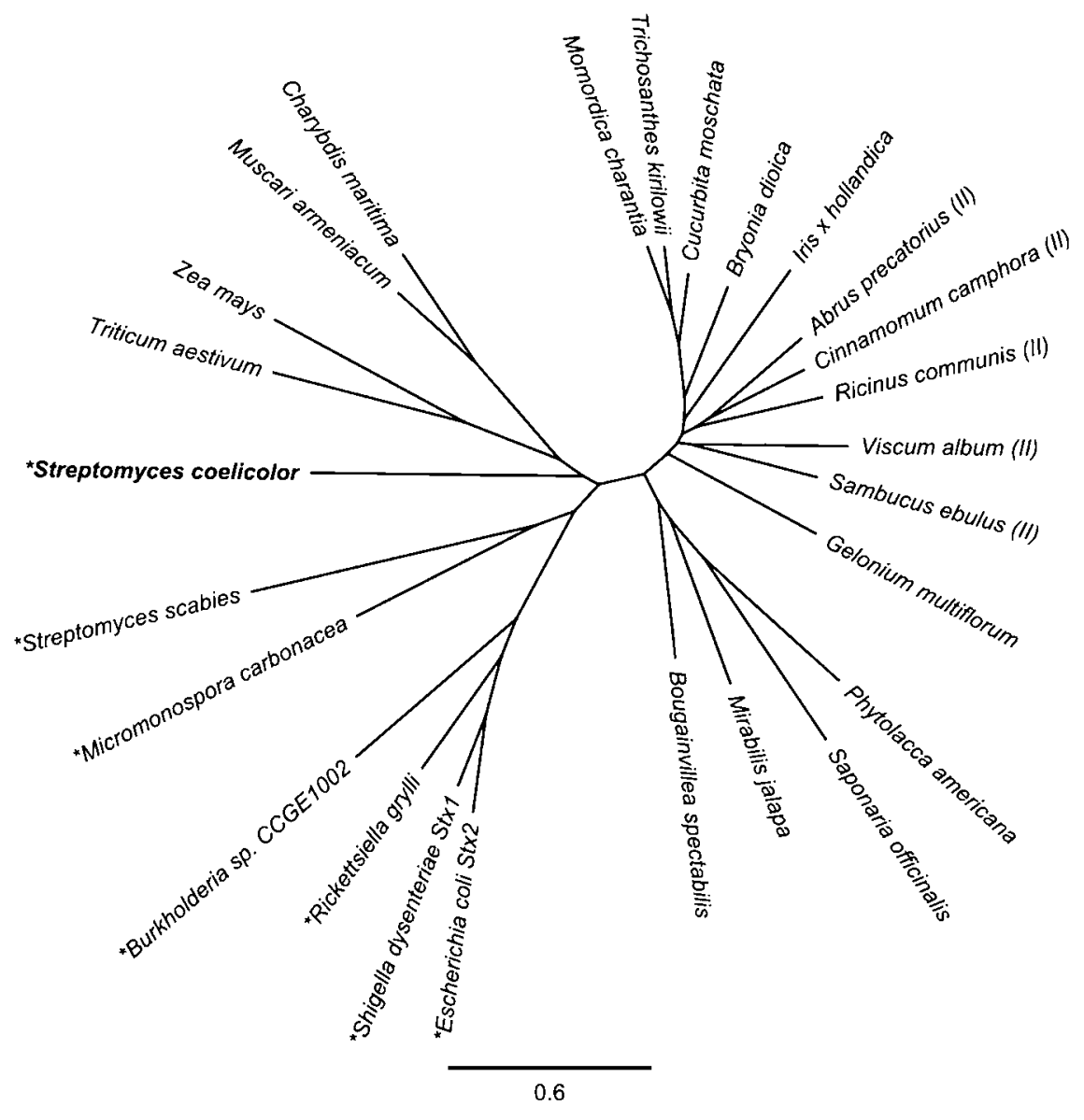

Fig. 1. Molecular phylogeny of plant RIPs and bacterial RIP-like proteins. Multiple alignment of the respective RIP domains (Supplementary Fig. S1) was used to construct the phylogenetic tree (for details see Supplementary Fig. S2). The scale bar represents 0.6 substitutions per site. Type II plant RIPs and bacterial RIP-like proteins are labelled with (II) and asterisks, respectively. Stx refers to subunit $A$ of Shiga toxins. 
other actinomycetes, namely the antibiotic producer Micromonospora carbonacea (Hosted et al., 2001) and Streptomyces scabies, a phytopathogen causing scab on potatoes (Lerat et al., 2009). Notably, the predicted M. carbonacea gene product carries a unique carboxy-terminal extension of about 280 amino acids. Our analysis suggests that the SCO7092 gene has evolved from a different ancestor, possibly of plant origin (Fig. 1).

\section{Overexpression of SCO7092 in S. lividans}

To study the biological properties of RIPsc, the purified protein was needed. Since we preferred purification of RIPsc from its natural source, we analysed the levels of SCO7092 expression in wild-type S. lividans at different stages of growth by RT-PCR. However, SCO7092 expression was not detectable when $S$. lividans was grown in liquid NM medium at $27{ }^{\circ} \mathrm{C}$ with continuous shaking at 300 r.p.m. (results not shown), while under other growth conditions, SCO7092 expression could be detected (results not shown).

Since RIPsc could not be purified from wild-type S. coelicolor or S. lividans, overexpression of ripsc in S. lividans was performed. To this end, we used the $v s i$-based expression system, which has been shown to be successful for the secretory production of several homologous and heterologous proteins in Streptomyces (Van Mellaert \& Anné, 2001; Sianidis et al., 2006). Consequently, the ripsc gene encoding the predicted mature protein was cloned into the Streptomyces multicopy plasmid pIJ486 downstream of the strong vsi promoter and signal sequence. However, introduction of the resulting pIJ486vsirip plasmid into $S$. lividans induced dramatic phenotypic effects. In particular, S. lividans cells harbouring pIJ486vsirip grew significantly slower than the wild-type and showed delayed sporulation in comparison with the wild-type (results not shown). Western blot analyses of culture filtrates obtained from S. lividans [pIJ486vsirip] after 24 and $48 \mathrm{~h}$ of growth showed production and secretion of RIPsc into the culture medium (Fig. 2), although the levels obtained were too low for purification purposes, most likely because RIPsc overproduction is toxic to S. lividans.

\section{Expression of SC07092 in E. coli}

For overexpression of the S. coelicolor ripsc gene in E. coli BL21(DE3)pLysS, a PCR-amplified DNA fragment bearing the gene encoding mature RIPsc (i.e. without the signal sequence) was inserted in pET3a downstream of the T7 promoter (resulting in pET-RIPsc). We chose the E. coli BL21(DE3)pLysS strain, since it expresses endogenous T7 lysozyme, which reduces basal expression of toxic proteins. The strain has been used successfully for overproduction of a type I plant RIP before (Antolín et al., 2004). From IPTGinduced cultures, samples were taken 0,2 , and $4 \mathrm{~h}$ after induction, and total cell lysates were analysed by SDSPAGE analysis. At the same time, soluble and insoluble

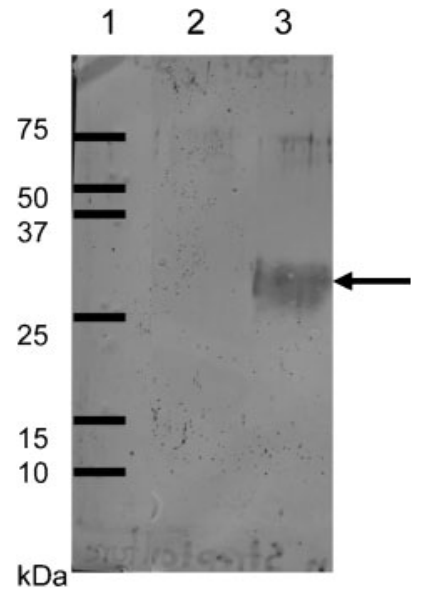

Fig. 2. Western blotting analysis (12.5\% SDS-polyacrylamide gel) of extracellular proteins from wild-type $S$. coelicolor (lane 2 ) and $S$. coelicolor cells harbouring plJ486RIPsc (lane 3) cultured in NM medium for $24 \mathrm{~h}$. The proteins were visualized using immunodetection with anti-RIPsc antibodies. The Precision Plus protein marker (Bio-Rad) was loaded in lane 1.

protein fractions were separated to determine whether the expression product was present as a soluble protein in the cytoplasm or as an insoluble aggregate in inclusion bodies. As seen in Fig. 3(a), RIPsc was efficiently produced in E. coli, although the RIPsc protein was only detectable in the insoluble protein fraction.

Several attempts were made to obtain soluble RIPsc protein, i.e. testing different E. coli host strains [E. coli BL21(DE3)star, E. coli JM109BL21(DE3), E. coli C43BL21(DE3] and E. coli DH5 $\alpha$ ), lowering the growth temperature to $27{ }^{\circ} \mathrm{C}$ and decreasing the IPTG concentration to $0.1 \mathrm{mM}$. However, in none of these cases was a significant amount of RIPsc observed in the soluble protein fraction. Nevertheless, the dramatic decrease of the growth rate and finally growth arrest of the culture after IPTG induction (Fig. $3 \mathrm{~b}$ ) suggested that although we could not detect it by Western blotting, some RIPsc was produced as a functional protein, exerting a cytotoxic effect.

\section{Purification of the SC07092 protein from E. coli}

Because the amounts of secreted RIPsc in S. lividans [pIJ486virip] were too low for purification purposes, the $S$. coelicolor RIPsc protein was purified after overproduction in E. coli from inclusion bodies as described in Methods. In brief, inclusion bodies were isolated from RIPsc-producing E. coli cells and extensively washed. The resulting proteins were then denatured in $8 \mathrm{M}$ urea and the RIPsc protein was purified from the sample by affinity chromatography on a $\mathrm{Ni}^{2+}$-NTA column under denaturing conditions. Evaluation of different refolding procedures demonstrated that for RIPsc, quick removal of urea using gel filtration chromatography was the optimal method to obtain 
(a) $\quad \begin{array}{llll}1 & 2 & 3 & 4\end{array}$

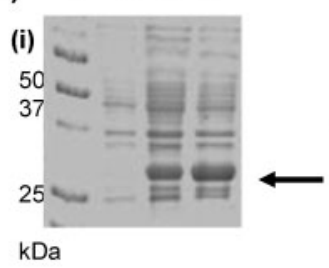

(ii)

(iii)
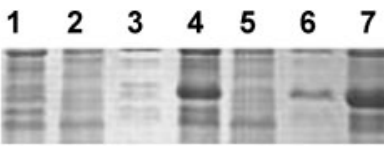

89

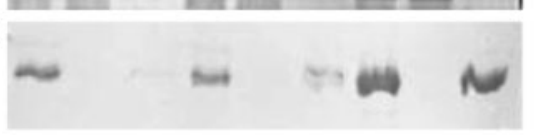

(b)

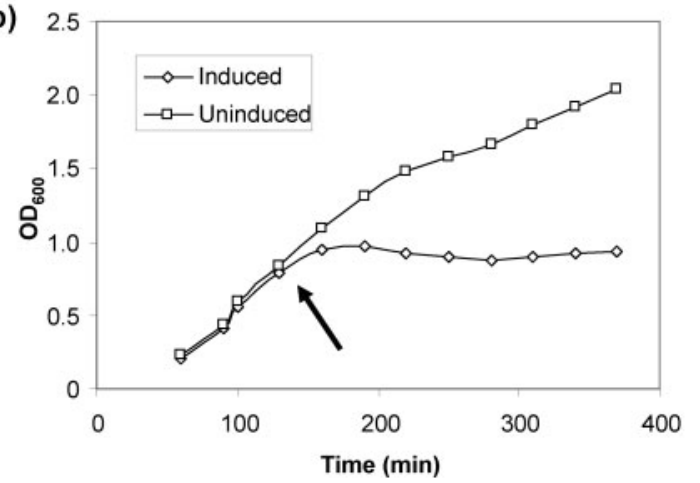

(c)

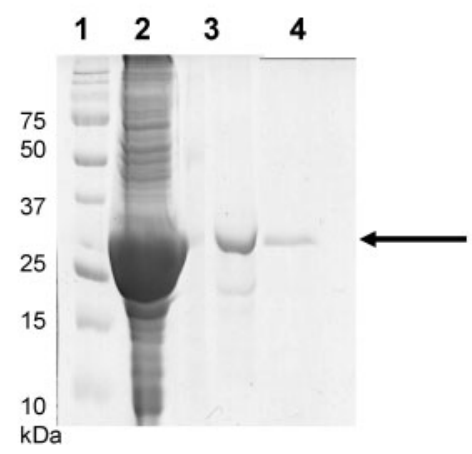

Fig. 3. (a) (i) Coomassie brilliant blue-stained $12.5 \%$ SDS-polyacrylamide gel showing $S$. coelicolor ripsc overexpression in $E$. coli BL21(DE3)pLysS. Lanes: 1, Precision Plus protein marker (Bio-Rad); 2, cell lysate of noninduced E. coli BL21(DE3)pLysS [pETRIPsc]; 3 and 4, cell lysates of $E$. coli BL21(DE3)pLysS [pETRIPsc] 2 and $4 \mathrm{~h}$ after IPTG induction. (ii, iii) Coomassie brilliant blue-stained $12.5 \%$ SDS-polyacrylamide gel (ii) and Western blotting analysis (iii) of soluble and insoluble protein extracts from $E$. coli BL21(DE3)pLysS harbouring pETRIPsc, showing the localization of RIPsc in $E$. coli BL21(DE3)pLysS. The proteins were visualized using immunodetection with anti-RIPsc antibodies. Lanes: 1, 4 and 7, total cell lysates from non-induced $E$. coli BL21(DE3)pLysS [pETRIPsc] and cells at 2 and $4 \mathrm{~h}$ after IPTG induction; 2, 5 and 8, soluble proteins extracted from non-induced $E$. coli BL21(DE3)pLysS [pETRIPsc] and cells at 2 and $4 \mathrm{~h}$ after IPTG induction; 3, 6 and 9, insoluble proteins extracted from non-induced E. coli BL21(DE3)pLysS [pETRIPsc] and cells at 2 and $4 \mathrm{~h}$ after IPTG induction. Arrows indicate the RIPsc protein. (b) Growth of E. coli BL21(DE3)pLysS harbouring pETRIPsc. Two cultures were grown at $37{ }^{\circ} \mathrm{C}$ and the $\mathrm{OD}_{600}$ was monitored as a function of time. When the $\mathrm{OD}_{600}$ reached 0.8, $1 \mathrm{mM}$ IPTG was added to one of the cultures to induce RIPsc production (arrow). Both cultures were further incubated at $37{ }^{\circ} \mathrm{C}$ for 4 h. (c) Overview of the purification of RIPsc visualized using a Coomassie brilliant blue-stained $12.5 \%$ SDS-polyacrylamide gel. Lanes: 1, size marker; 2, inclusion bodies isolated from $E$. coli BL21(DE3)pLysS harbouring pETRIPsc; 3 , elution fraction from the $\mathrm{Ni}^{2+}$. NTA column containing RIPsc; 4, RIPsc after refolding by gel filtration. sufficient amounts of soluble protein. Samples showing the purity of the RIPsc protein during the different stages of purification are shown in Fig. 3(c). From inclusion bodies isolated from a $600 \mathrm{ml}$ IPTG-induced culture, approximately $50-100 \mu \mathrm{g}>85 \%$ pure denatured RIPsc protein was retrieved. After the refolding step, about 5-10 $\mathrm{gg}$ refolded RIPsc protein could be obtained.

\section{Translation inhibition in rabbit reticulocyte lysates by SCO7092}

The best-known activity of RIPs is translational inhibition, which is caused by depurination of $\mathrm{A}_{4324}$ (or removal of an equivalent base in other ribosomes) in the $28 \mathrm{~S}$ rRNA of the eukaryotic ribosome, which is essential for translation. Here, we evaluated the effect of RIPsc on ribosomes by assaying its inhibitory activity on protein synthesis by a rabbit reticulocyte lysate. All RIPs described so far have been shown to inhibit protein synthesis, although with very different potencies.

In particular, we tested whether purified recombinant RIPsc was able to inhibit luciferase translation in a rabbit reticulocyte translation system. Rabbit reticulocytes were incubated with increasing concentrations of these protein preparations $\left(125,250,500 \mathrm{ng}\right.$ each) for $30 \mathrm{~min}$ at $30{ }^{\circ} \mathrm{C}$ before translation was initiated. Untreated rabbit reticulocytes served as negative control. Fig. 4 shows that when purified RIPsc was added to the reaction mixture, the amount of luciferase produced in vitro was strongly reduced. The inhibitory effect was found to increase with rising RIPsc concentration. These experiments show that RIPsc specifically inhibits protein translation of rabbit ribosomes. 


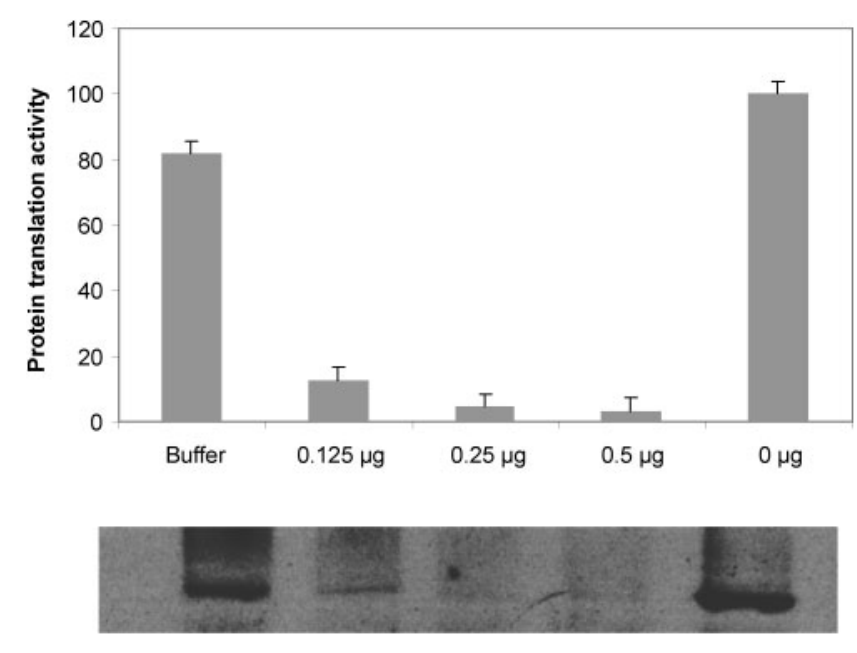

Fig. 4. Inhibition of in vitro protein synthesis by RIPsc as a percentage of the untreated control. Rabbit reticulocytes were incubated with $0.5,0.25$ or $0.125 \mu \mathrm{g}$ purified RIPsc at $30{ }^{\circ} \mathrm{C}$ for $30 \mathrm{~min}$. The treated rabbit reticulocytes were then incubated for $1 \mathrm{~h}$ with luciferase mRNA. In order to detect the translation products, the denatured samples were separated by $12.5 \%$ SDSPAGE and then transferred to a PVDF membrane for chemiluminescence detection of newly synthesized protein (Promega). Lanes: 1, buffer control; 2, $0.125 \mu \mathrm{g}$ RIPsc; 3, $0.25 \mu \mathrm{g}$ RIPsc; 4, $0.5 \mu \mathrm{g}$ RIPsc; 5, $0 \mu \mathrm{g}$ RIPsc. Bars represent the average of two independent experiments. The lower part of the figure shows the visualized bands on X-ray films, which were used to calculate the percentage chemiluminescence for the different samples.

\section{N-Glycosidase activity of SCO7092}

$\mathrm{N}$-Glycosidase activity of recombinant RIPsc was demonstrated by a novel RIP assay (Melchior \& Tolleson, 2010). This assay is based on the fact that reverse transcriptase usually incorporates an adenosine when it encounters a site with a lesion on the template strand. RIP activity was monitored for RNA samples taken from uninduced and induced cells of E. coli BL21(DE3)pLysS transformed with pET-RIPsc. If the produced protein has damaged the rRNA, reverse transcriptase will insert an adenosine into complementary DNA during qRT-PCR. Provided that a site-specific PCR primer is used, a higher amplification of the altered sequence results. Fig. 5 shows a strong increase in the target amplicon following induction of RIPsc expression, in comparison with the control (template from culture without induction). This shows that RIPsc is removing the specific adenine from $\mathrm{rRNA}$ within a universally conserved GAGA sequence $\left(\mathrm{A}_{2660}\right.$ in the case of E. coli $23 \mathrm{~S}$ rRNA).

\section{Antifungal activity of SC07092}

Most RIPs have been shown to be able to inactivate fungal ribosomes. Recent studies also suggest that some RIPs can directly inhibit certain fungi by inactivating their ribosomes and causing cell death. For the latter, internalization
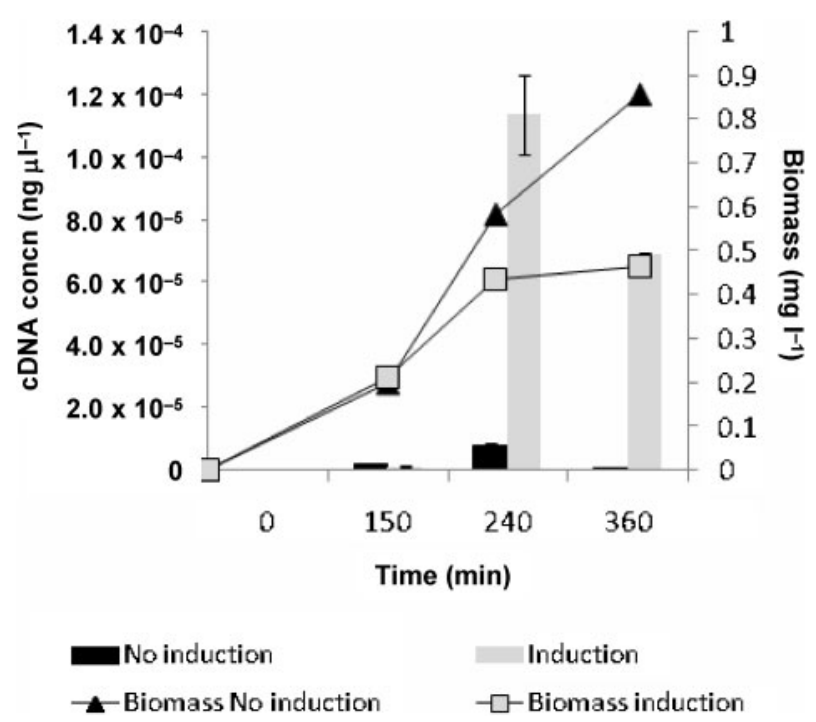

Fig. 5. rRNA $N$-deglycosylation activity of RIPsc expressed in E. coli. Total E. coli RNA, for use as template in a qRT-PCR assay of RIP activity, was isolated at different time points from two different cultures. The cultures consisted of $48 \mathrm{ml}$ LB medium inoculated with $2 \mathrm{ml}$ overnight preculture of $E$. coli (pET-RIPsc) and incubated at $37{ }^{\circ} \mathrm{C}$. After reaching $\mathrm{OD}_{600} 0.8$, one culture was induced by the addition of $1 \mathrm{mM}$ IPTG. The second culture was used as a control, without induction. The amount of cDNA produced is proportional to the enzymic activity of RIP towards target rRNA.

of the RIP protein is necessary to exert fungicidal activity (Park et al. 2002a). Firstly, to analyse whether S. coelicolor RIPsc can inactivate fungal ribosomes and has potent in vivo antifungal activity, we evaluated the effect of intracellular expression of SCO7092 in Saccharomyces cerevisiae. The SCO7092 gene encoding the predicted mature protein was cloned under the control of a galactose-inducible promoter and the effect of SCO7092 expression on yeast was evaluated with a spot test. Fig. 6 shows that SCO7092 expression results in strong inhibition of Saccharomyces cerevisiae growth.

Secondly, the effect of exogenously supplied purified RIPsc on the growth of various fungi was investigated. Of these, Fusarium oxysporum and Trichoderma reesei have been shown to be inhibited by certain RIPs (Sharma et al., 2004; Park et al., 2002a, b; Vivanco et al., 1999; Roberts \& Selitrennikoff, 1986). However, using a radial growth inhibition assay with Saccharomyces cerevisiae and three other fungi, F. oxysporum, T. reesei and A. niger, no significant antifungal activity could be observed for RIPsc (data not shown). Hence, RIPsc does not belong to the small group of type I RIPs that are able to inhibit fungal growth (Sharma et al., 2004; Park et al., 2002a, b; Vivanco et al., 1999; Roberts \& Selitrennikoff, 1986). The absence of a lectin-type chain most likely hampers the ability of the protein to enter the cell. 


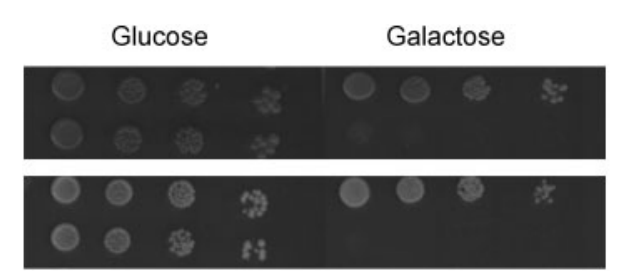

S. cerevisiae W303-1A [pESC]

S. cerevisiae W303-1A [pESC-ripsc]

S. cerevisiae BY4743 [pESC]

S. cerevisiae BY4743 [pESC-ripsc]
Fig. 6. Spot test to analyse RIPsc toxicity to yeast. Equal numbers of Saccharomyces cerevisiae [pESC] or Saccharomyces cerevisiae cells harbouring $\mathrm{pESC}$-ripsc were spotted on media with glucose or galactose to induce RIPsc production. The cells were incubated for $15 \mathrm{~h}$ at $30{ }^{\circ} \mathrm{C}$.
Antibacterial activity of SCO7092 Intracellular expression of SCO7092 in E. coli (see above) already suggested that SCO7092 expression is toxic for E. coli cells. Consequently, the potential antibacterial activity of exogenously applied RIPsc was evaluated using representative Gram-positive and Gram-negative bacteria, i.e. Staphylococcus aureus, Staphylococcus epidermidis, M. luteus, B. subtilis, $P$. aeruginosa and $E$. coli. No antibacterial activity against the tested bacteria was detected (results not shown), most likely because of the inability of RIPsc to enter the bacterial cell.

\section{DISCUSSION}

In this manuscript, we describe the identification and characterization of a new RIP-like protein from the Grampositive soil bacterium S. coelicolor. Several pathogenic $\gamma$ proteobacteria (Shigella. dysenteriae, E. coli STEC strains and species of Aeromonas, Citrobacter and Enterobacter) have been shown to produce potent cytotoxic type II RIPs involved in human and animal disease (Sandvig, 2006). However, following our phylogenetic analyses, the $S$. coelicolor protein appears to be more related to plant type I RIPs than to these Shiga and Shiga-like toxins.

The efficiency of rip expression in bacterial systems has been shown to be highly variable. The cDNA of some type I plant RIPs has been expressed successfully at high levels (Rajamohan et al., 1999; Chi et al., 2001). In some cases, the recombinant RIP is inactive or far less active than the native protein ( $\mathrm{Wu}$ et al., 1998). Conversely, some other RIPs heterologously expressed strongly promote bacterial ribosome inactivation, causing cell growth arrest (Cho et al., 2000). Finally, some recombinant RIPs are produced as inclusion bodies (Antolín et al., 2004). The dramatic decrease in growth rate of $E$. coli upon induction of ripsc expression strongly suggests that RIPsc overproduction is highly toxic to E. coli. Similar results have also been obtained in the case of expression of type I RIPs from Mirabilis jalapa (Kataoka et al., 1991), Phytolacca americana, Dianthus sinensis (Cho et al., 2000), Amaranthus viridis (Kwon et al., 2000) and Beta vulgaris (Iglesias et al., 2005) in E. coli cells under inducing conditions. In E. coli, accumulation of RIPsc to high levels could only be observed when the protein was produced as inactive protein in inclusion bodies, most likely because of its inherent toxicity. In this respect, it is also interesting to mention that RIPsc overproduction resulted in a decreased growth rate of its natural host, Streptomyces.
The translational inhibitory activity of purified RIPsc in a rabbit reticulocyte system was of the same order of magnitude as those of other type I RIPs, such as musarmin 1 from Muscari armeniacum (Antolín et al., 2004) and TRIP from tobacco (Sharma et al., 2004). This suggests that solubilization of the protein from inclusion bodies and refolding of RIPsc yielded fully active protein.

A novel RT-PCR assay for the $\mathrm{N}$-glycosidase activity of RIPs (Melchior \& Tolleson, 2010) was used to analyse directly the predicted enzymic activity towards rRNA of the ripsc gene product. The amplification of the damaged fragment of E. coli $23 \mathrm{~S}$ rRNA which contains the specific adenine $\left(\mathrm{A}_{2660}\right)$ target of RIPs confirmed the identity of the protein as a novel prokaryotic RIP.

The potential antimicrobial activity of RIPsc in vivo was examined by testing its effect on the growth of different fungi and bacteria. When produced in the cytosol of E. coli and Saccharomyces cerevisiae, the RIPsc protein was found to efficiently inhibit cell growth. However, when added to bacterial cells or fungi extracellularly, we could not observe any antimicrobial activity. Consequently, a direct role of RIPsc in antagonism of bacterial and fungal competitors is very unlikely. We assume that the observed lack of antibacterial and antifungal activity of RIPsc is related to the absence of a lectin-type chain, which is present in the more toxic type II RIPs, and which is thought to assist the protein in entering target cells (Stirpe, 2004; Stirpe \& Battelli, 2006). Given the high toxicity of the protein when produced in the cytosol of E. coli and Saccharomyces cerevisiae, it is therefore envisioned that fusion of the RIPsc protein to a lectin could make this protein an efficient antimicrobial compound.

\section{ACKNOWLEDGEMENTS}

This work was supported by the América Latina - Formación Académica (ALFA) grant ALFA II-0313-FA-FCB.

\section{REFERENCES}

Anné, J., Van Mellaert, L. \& Eyssen, H. (1990). Optimum conditions for efficient transformation of Streptomyces venezuelae protoplasts. Appl Microbiol Biotechnol 32, 431-435.

Antolín, P., Girotti, A., Arias, F. J., Barriuso, B., Jiménez, P., Rojo, M. A. \& Girbés, T. (2004). Bacterial expression of biologically active recombinant musarmin 1 from bulbs of Muscari armeniacum L. and Miller. J Biotechnol 112, 313-322. 
Barbieri, L., Battelli, M. G. \& Stirpe, F. (1993). Ribosome-inactivating proteins from plants. Biochim Biophys Acta 1154, 237-282.

Bentley, S. D., Chater, K. F., Cerdeño-Tárraga, A. M., Challis, G. L., Thomson, N. R., James, K. D., Harris, D. E., Quail, M. A., Kieser, H. \& other authors (2002). Complete genome sequence of the model actinomycete Streptomyces coelicolor A3(2). Nature 417, 141-147.

Brachmann, C. B., Davies, A., Cost, G. J., Caputo, E., Li, J., Hieter, P. \& Boeke, J. D. (1998). Designer deletion strains derived from Saccharomyces cerevisiae S288C: a useful set of strains and plasmids for PCR-mediated gene disruption and other applications. Yeast 14, $115-132$.

Chi, P. V., Truong, H. Q., Ha, N. T., Chung, W. I. \& Binh, L. T. (2001). Characterisation of trichobakin, a type I ribosome-inactivating protein from Trichosanthes sp. Bac Kan 8-98. Biotechnol Appl Biochem 34, 85-92.

Cho, H. J., Lee, S. J., Kim, S. \& Kim, B. D. (2000). Isolation and characterisation of cDNAs encoding ribosome-inactivating protein from Dianthus sinensis L. Mol Cells 10, 135-141.

Endo, Y., Gluck, A. \& Wool, I. G. (1991). Ribosomal RNA identity elements for ricin A-chain recognition and catalysis. J Mol Biol 221, 193-207.

Geukens, N., Lammertyn, E., Van Mellaert, L., Schacht, S., Schaerlaekens, K., Parro, V., Bron, S., Engelborghs, Y., Mellado, R. P. \& Anné, J. (2001). Membrane topology of the Streptomyces lividans type I signal peptidases. J Bacteriol 183, 4752-4760.

Gietz, R. D., Schiestl, R. H., Willems, A. R. \& Woods, R. A. (1995). Studies on the transformation of intact yeast cells by the LiAc/SSDNA/PEG procedure. Yeast 11, 355-360.

Girbés, T., Ferreras, J. M., Arias, F. J. \& Stirpe, F. (2004). Description, distribution, activity and phylogenetic relationship of ribosomeinactivating proteins in plants, fungi and bacteria. Mini Rev Med Chem 4, 461-476.

Hosted, T. J., Wang, T. X., Alexander, D. C. \& Horan, A. C. (2001) Characterization of the biosynthetic gene cluster for the oligosaccharide antibiotic, Evernimicin, in Micromonospora carbonacea var. africana ATCC 39149. J Ind Microbiol Biotechnol 27, 386-392.

Iglesias, R., Pérez, Y., de Torre, C., Ferreras, J. M., Antolín, P., Jiménez, P., Rojo, M. A., Méndez, E. \& Girbés, T. (2005). Molecular characterization and systemic induction of single-chain ribosomeinactivating proteins (RIPs) in sugar beet (Beta vulgaris) leaves. J Exp Bot 56, 1675-1684.

Johannes, L. \& Römer, W. (2010). Shiga toxins - from cell biology to biomedical applications. Nat Rev Microbiol 8, 105-116.

Kataoka, J., Habuka, N., Miyano, M., Takanami, Y. \& Koiwa, A. (1991). DNA sequence of Mirabilis antiviral protein (MAP), a ribosomeinactivating protein with antiviral property, from Mirabilis jalapa L. and its expression in E. coli. J Biol Chem 266, 8426-8430.

Kieser, T., Bibb, M. J., Buttner, M. J., Chater, K. F. \& Hopwood, D. A. (2000). Practical Streptomyces Genetics. Norwich: John Innes Foundation.

Korn, F., Weingärtner, B. \& Kutzner, H. J. (1978). A study of twenty actinophages: morphology, serological relationship and host range. In Genetics of the Actinomycetales, pp. 251-270. Edited by E. Freechsen, I. Tarnak \& J. H. Thumin. Stuttgart: G. Fischer Verlag.

Kwon, S. Y., An, C. S., Liu, J. R., Kwak, S.-S., Lee, H. S., Lim, J. K. \& Paek, K. H. (2000). Molecular cloning of a cDNA encoding ribosomeinactivating protein from Amaranthus viridis and its expression in E. coli. Mol Cells 10, 8-12.

Lammertyn, E. (2000). Isolation and characterisation of a novel subtilisin inhibitor gene from Streptomyces venezuelae and evaluation of its regulatory sequences for heterologous protein secretion by
Streptomyces lividans. $\mathrm{PhD}$ thesis, Katholieke Universiteit Leuven, Leuven, Belgium.

Leclerque, A. (2008). Whole genome-based assessment of the taxonomic position of the arthropod pathogenic bacterium Rickettsiella grylli. FEMS Microbiol Lett 283, 117-127.

Lerat, S., Simao-Beaunoir, A. M. \& Beaulieu, C. (2009). Genetic and physiological determinants of Streptomyces scabies pathogenicity. Mol Plant Pathol 10, 579-585.

Lord, J. M., Roberts, L. M. \& Robertus, J. D. (1994). Ricin: structure, mode of action, and some current applications. FASEB J 8, 201-208.

Melchior, W. B., Jr \& Tolleson, W. H. (2010). A functional quantitative polymerase chain reaction assay for ricin, Shiga toxin, and related ribosome-inactivating proteins. Anal Biochem 396, 204-211.

Ng, T. B., Wong, J. H. \& Wang, H. (2010). Recent progress in research on ribosome inactivating proteins. Curr Protein Pept Sci 11, 37-53.

Park, S. W., Stevens, N. M. \& Vivanco, J. M. (2002a). Enzymatic specificity of three ribosome-inactivating proteins against fungal ribosomes, and correlation with antifungal activity. Planta 216, 227234.

Park, S. W., Lawrence, C. B., Linden, J. C. \& Vivanco, J. M. (2002b). Isolation and characterization of a novel ribosome-inactivating protein from root cultures of pokeweed and its mechanism of secretion from roots. Plant Physiol 130, 164-178.

Park, S. W., Prithiviraj, B., Vepachedu, R. \& Vivanco, J. M. (2006). Isolation and purification of ribosome-inactivating proteins. Methods Mol Biol 318, 335-347.

Rajamohan, F., Engstrom, C. R., Denton, T. J., Engen, L. A., Kourinov, I. \& Uckun, F. M. (1999). High-level expression and purification of biologically active recombinant pokeweed antiviral protein. Protein Expr Purif 16, 359-368.

Roberts, W. K. \& Selitrennikoff, C. P. (1986). Isolation and partial characterization of two antifungal proteins from barley. Biochim Biophys Acta 880, 161-170.

Sambrook, J., Fritsch, E. F. \& Maniatis, T. (1989). Molecular Cloning: a Laboratory Manual, 2nd edn. Cold Spring Harbor, NY: Cold Spring Harbor Laboratory.

Sandvig, K. (2001). Shiga toxins. Toxicon 39, 1629-1635.

Sandvig, K. (2006). The Shiga toxins: properties and actions on cells. In The Comprehensive Sourcebook of Bacterial Toxins, 3rd edn, pp. 310-322. Edited by J. E. Alouf \& M. R. Popoff. San Diego, CA: Academic Press.

Schlumbaum, A., Mauch, F., Vogeli, U. \& Boller, T. (1986). Plant chitinases are potent inhibitors of fungal growth. Nature 324, 365367.

Sharma, N., Park, S. W., Vepachedu, R., Barbieri, L., Ciani, M., Stirpe, F., Savary, B. J. \& Vivanco, J. M. (2004). Isolation and characterisation of a RIP-like protein from tobacco with dual enzymatic activity. Plant Physiol 134, 171-181.

Sianidis, G., Pozidis, C., Becker, F., Vrancken, K., Sjoeholm, C., Karamanou, S., Takano-Wik, M., Van Mellaert, L., Schaeffer, Th. \& other authors (2006). Functional large-scale production of a novel Jonesia sp. xyloglucanase by heterologous secretion from Streptomyces lividans. J Biotechnol 121, 498-507.

Stirpe, F. (2004). Ribosome-inactivating proteins. Toxicon 44, 371383.

Stirpe, F. \& Battelli, M. G. (2006). Ribosome-inactivating proteins: progress and problems. Cell Mol Life Sci 63, 1850-1866.

Stirpe, F., Barbieri, L., Batelli, M. G., Soria, M. \& Lappi, D. A. (1992). Ribosome-inactivating proteins from plants: present status and future prospects. Biotechnology (N Y) 10, 405-412. 
Studier, F. W., Rosenberg, A. H., Dunn, J. J. \& Dubendorff, J. W. (1990). Use of T7 RNA polymerase to direct expression of cloned genes. Methods Enzymol 185, 60-89.

Suh, J. K., Hovde, C. J. \& Robertus, J. D. (1998). Shiga toxin attacks bacterial ribosomes as effectively as eukaryotic ribosomes. Biochemistry 37, 9394-9398.

Thomas, B. J. \& Rothstein, R. (1989). Elevated recombination rates in transcriptionally active DNA. Cell 56, 619-630.

Van Mellaert, L. \& Anné, J. (2001) Gram-positive bacteria for the heterologous production of biopharmaceutical compounds. In Focus on Biotechnology, vol. I, pp. 277-300, Novel Frontiers in the Production of Compounds for Biomedical Use. Edited by A. Van Broekhoven, F. Shapiro \& J. Anné. Dordrecht, The Netherlands: Kluwer Academic Publishers.

Van Mellaert, L., Dillen, C., Proost, P., Sablon, E., Deleys, R., Van Broekhoven, A., Heremans, H., Van Damme, J., Eyssen, H. \& Anné, J.
(1994). Efficient secretion of biologically active mouse tumor necrosis factor $\alpha$ by Streptomyces lividans. Gene 150, 153-158.

Vivanco, J. M., Savary, B. J. \& Flores, H. E. (1999). Characterization of two novel type I ribosome-inactivating proteins from the storage roots of the andean crop Mirabilis expansa. Plant Physiol 119, 14471456.

Ward, J. M., Janssen, G. R., Kieser, T., Bibb, M. J., Buttner, M. J. \& Hopwood, D. A. (1986). Construction and characterisation of a series of multi-copy promoter-probe plasmid vectors for Streptomyces using aminoglycoside phosphotransferase gene from Tn5 as indicator. Mol Gen Genet 203, 468-478.

Wu, T. H., Chow, L. P. \& Lin, J. Y. (1998). Sechiumin, a ribosomeinactivating protein from the edible gourd, characterisation, molecular cloning and expression. Eur J Biochem 255, 400-408.

Edited by: T. J. Mitchell 